\title{
5 \\ The social ecology of artisanal mining: Between romanticisation and anathema
}

Saleem H. Ali

Artisanal and small-scale mining (ASM) has existed for millennia, and is ingrained in many cultural traditions. However, as this book's first four chapters have demonstrated, the activity has often faced challenges of acceptance by mainstream institutions because it occupies an interstitial space 'between the pick and the plough'. It is at once an extractive sector but is also practised as a seasonal activity of agrarian peasants. It may not have all the hallmarks of a formal enterprise, but it is also seldom anarchic plundering of a resource. Thus, in this chapter, I attempt to negotiate through these seemingly conflicting elements of ASM by offering a synthetic conceptual anchor for the preceding chapters. I am guided in this task by an acute recognition that environmental concerns about ASM would need to be addressed in any effective framing of its social development imperative.

Development donors have considered ASM as suitable for technical interventions to improve yield of minerals or alternative techniques for safer extraction. The World Bank and the Communities and Small-Scale Mining (CASM) program ${ }^{1}$ was operational from 2000 to 2010, and developed a

1 Details of the CASM program of work can be found at World Bank (2008). 
broad repertoire of information exchange in this arena. The United Nations Industrial Development Organization (UNIDO) and Swiss Development Agency's efforts to focus on the use of mercury in ASM gold-mining are examples of such undertakings. Mercury reduction efforts have been spurred by the advent of the Minamata Convention on Mercury Reduction that has thus far been signed by over 128 countries, and ratified by 88 (as of January 2018). ${ }^{2}$ The Convention recognises that mercury usage in artisanal and small-scale mining will likely be a challenge for many more years to come, given the remote locations of the mining sites and the relatively low cost of mercury worldwide. More recently, United Nations Development Programme (UNDP) has also started to engage with low-value minerals and the role of ASM in quarrying of industrial and construction materials, particularly in African, Caribbean and Pacific Island states (See UNDP 2015 for details of the program).

The goal of this chapter is to make the argument that all these laudable efforts need to consider the overall trajectory from a broader socioecological sustainability lens. Regulation-from tax collection, to environmental health and safety concerns, to conflict determinismhas vexed development practitioners for decades. Given the current context of sustainable development and the advent in 2015 of the 17 Sustainable Development Goals (SDGs), ASM should be considered as part of a hybrid livelihood strategy or a transitional opportunity for catalysing development. Thus, it is imperative that we find a more meaningful theoretical construct that could have broader development planning activity in order to ameliorate the plight of miners and assuage the concerns of governments alike.

\section{The relevance of social ecology theory}

The term 'social ecology' has developed in two parallel intellectual traditions that have seldom communicated with each other, despite having congruent objectives. First, the concept of social ecology was developed in psychological discourse, particularly by Arnold Binder (1974), and found grounding at the University of California through the establishment of the School of Social Ecology. The core aspects of this approach were subsequently summarised in six principles by Dave Taylor (1999) as follows:

2 A frequently updated status of Minamata signatories is available at www.mercuryconvention.org/ 
- Identify a phenomenon as a social problem.

- View the problem from multiple levels and methods of analysis.

- Utilise and apply diverse theoretical perspectives.

- Recognise human-environment interactions as dynamic and active processes.

- Consider the social, historical, cultural and institutional contexts of people-environment relations.

- Understand people's lives in an everyday sense.

The field in this inception builds upon traditions of human ecology, which were developed in geography, anthropology and environmental history. The context was that humans were an essential part of ecological systems and that environmental problem-solving must consider the transformative role of human societies on the environment.

Second, the term was embraced by the 'green anarchist' scholar Murray Bookchin as a response to what he perceived as a hierarchical approach to ecological problem-solving that was being posited in policy-making circles. Instead of regulating our way to solutions, Bookchin and his protégés at the Institute for Social Ecology (based in Plainfield, Vermont, USA) were focused on social transformation through decentralised inculcation of ecological ethics. It is important to note that through his intellectual development of social ecology, Bookchin dismissed some of the absolutist elements of anarchist thought around electoral participation. Instead, 'green anarchy' focused on how grassroots community organisations, which had direct connections to the land and livelihoods, could contribute effectively in local governance.

Despite his atheism, there was perhaps an inadvertent element of the Catholic social teaching of 'subsidiarity' within the approach posited by Bookchin as his writings matured, whereby the lowest functional level of governance was to be given ascendancy. Artisanal and small-scale mining cooperatives and localised governance forms are in congruence with such a paradigm as well. Interestingly enough, the most recent encyclical on ecology issued by Pope Francis, entitled Laudato si' (translated from medieval Italian as 'Praise be to You', and subtitled 'On Care For Our Common Home') echoes these themes of subsidiarity. At the 2015 conference of the Transnational Institute for Social Ecology, Ian Bekker astutely observed an 'overlap between the message of Laudato si' and the Social Ecology project of Murray Bookchin' (2015: 1). 
In the context of mining, it is particularly important to also consider that larger mining firms have been a frequent target of activism by Catholic charities. Overtures by some of the larger mining company executives to the Vatican in an effort to improve perception of their development impact with the church have achieved mixed results. On the one hand, the church continues to express strong concerns about the negative impact of large-scale mining in Catholic countries such as the Philippines. ${ }^{3}$ On the other hand, three major mining companies have been engaged in dialogue with the Vatican over a two-year project through the Kellogg Innovation Network. ${ }^{4}$ As with other social advocacy organisations, mining continues to pose a dilemma for the Vatican in terms of its long-term contribution towards sustainability. Minerals are noted as essential, and often their role as catalysts of development is recognised. Yet, the scale and scope of the activity remains contested at multiple levels.

Since ASM is largely a decentralised activity, and many of the major concerns ensue from its environmental impact, a social ecology approach, in either of its intellectual lineages, has potential for better policy formulation. The ongoing debates about the governance and benefits of artisanal and small-scale mining, and its relationship with large-scale mining, can benefit from what Bookchin (1995a) called 'dialectical naturalism'. Dialectical methods can broadly be conceived to have four fundamental principles, ${ }^{5}$ which Bookchin embraced, but with modifications:

- Human activities are transient and finite, existing in the medium of time.

- Human behaviour is composed of contradictions (opposing forces).

- Incremental changes lead to turning points when one force overcomes its opponent force (quantitative change leads to qualitative change).

- Change occurs in spiral not circular form-hence there is an evolution process that comes forth when contradictory perspectives interact with each other.

3 A summary of the Pope's concerns about mining can be found on the Vatican Radio (2015) website.

4 For details of the multi-faith outreach effort by the industry, refer to the Kellogg Innovation Network (2015) website, which has reports released in 2015.

5 These principles can be derived from a variety of texts on dialectics. An excellent framing of the use of this approach in organisations in policy and planning can be found in Mitroff and Emschoff (1979). 
Bookchin (2005) was quite conscious about differentiating his approach from what he termed Hegel's 'empyrean idealism' as well as what he called Marx's wooden, often scientistic dialectical materialism. His approach embraces science and society, as providing feedback loops towards more effective ecologically sustainable governance at a non-hierarchical localised level. Through the lens of social ecology, in its tradition of dialectical naturalism (Brincat and Gerber 2015), ASM has the potential to be structured as a decentralised activity, but it remains to be seen whether the ecological impacts can be managed within such a devolved paradigm. The Irvine social ecology framework provides us some guidance on how to better formulate our approach towards effective problem-solving of ASM. Through this process, some mechanisms of governance can be identified and the seemingly contradictory elements of 'thinking locally' about its social context but 'acting national or globally' on its ecological footprint can find some reconciliation. The spiralling trajectory of dialectical naturalism can thus lead us towards more ecologically viable livelihoods generated from ASM in the short term, and broader community development outcomes in the long term. However, such a pathway will require us to navigate in far greater detail specific aspects of ASM activity, in order to make the application of these lofty philosophical principles more palpable for decision makers.

\section{Applying social ecology concepts to ASM governance}

Artisanal mining is a highly arduous activity that is extremely difficult to govern. Thus, its role as a livelihood strategy needs to be considered in those terms, with a focus on improving the living condition of miners and affording improved government or community oversight. The remoteness and desperation of many communities in ASM make them easy targets for exploitative practices, including child labour and bondage. For many miners, particularly in the gemstone arena, this profession is a transitory career to find a prized stone, and then to move on to less risky professional pursuits. In other cases, the profession is seasonal, and coupled with agricultural practices and trade. Mining rushes can create a frenzy of resource extraction that can degrade land and water bodies to the point where these alternative livelihoods, particularly agriculture or fishing, become unviable. 
Much of the literature on ASM acknowledges that it is often a seasonal activity and that it can be considered a resilience strategy against downturns in agricultural productivity due to natural or anthropogenic activities. Even vociferous supporters of ASM as a development strategy acknowledge that those miners who engage in the activity for most of their lives do so because of poverty (Hilson 2010). The mineral 'rush' phenomenon associated with ASM, which can draw people from other professions, can occur with gemstone deposits (Cartier 2009) but is less prevalent with gold-mining. The difficulty of governing ASM within a conventional administrative framework has been amply documented in the literature on the challenges of 'formalization' efforts by governments (Lahiri-Dutt 2004). As a result of this challenge, social scientists have struggled to provide a meaningful theoretical frame whereby ASM governance could be operationalised, particularly with consideration of its ecological and health and safety impact on miners and communities. Siegel and Veiga (2009) attempted to use Hernado De Soto's theory of 'extra-legality' as a means of formulating a more effective governance mechanism for ASM. However, De Soto's approach as applied to ASM in this context aspires to coopt customary practices and use those as an 'extra-legal' formalisation process, which also transitions artisanal miners to careers in small- and medium-scale mining. The direct ecological impacts are not as clearly problematised by De Soto, nor have they been effectively addressed in terms of land use remediation and the long-term ecological impact of ASM. Perhaps the approach recently posited by Capra and Mattei (2015) in their book The Ecology of Law can provide better guidance in this regard. In their view, in order to have functional economies involving natural resource extraction, we need to transform 'legal institutions from being machines of extraction, rooted in the mechanistic functioning of private property and state authority, into institutions based on ecological communities' (ibid.: 5). Governance and regulatory enforcement, through such 'ecological communities' that have appropriate education on natural constraints of extraction, is likely to be the best way to manage ASM.

Often ASM governance gets framed in terms of risk management at the level of the individual, as well as collectively at the level of society. Human and environmental health exposure is perhaps the most direct encapsulation of this risk trade-off. However, this aspect of ASM has been addressed through numerous studies on technical solutions related to ASM usage of mercury (Sippl and Selin 2012) and cyanide exposure (Hilson and Monhemius 2006) in gold-mining. Mercury-use reduction targets in ASM gained momentum with a UNIDO/UNDP Global Mercury Project 
from 2002-07 that had a focal area on ASM, ${ }^{6}$ and particularly since the promulgation of the Minamata Convention on Mercury Reduction in 2013. Safety concerns are also being addressed through distribution of personal protective equipment by non-profit organisations; although this area still deserves far greater attention (Smith et al. 2016).

However, the ecological externalities generated by ASM remain an imponderable aspect of the 'extra-legal' approach, especially since many miners are migrants and have little traditional connection to the activity. Retorts that might reduce mercury exposure to the miner can still be a contaminant in the environment if improperly disposed. Where ecological factors have been included through a reclamation plan, such as the work of the Asia Foundation and the Swiss Development Corporation in Mongolia, there has been some local government enforcement interface (Lindberg and Purevjav 2013).

The social ecology approach allows us to consider this deficiency in the current frame of analysis around ASM. Since much of the criticism comes from the environmental damage and the negative impact on other potential land uses that ASM can cause, addressing those challenges will be absolutely critical. The career trajectories of miners appear to be highly heterogeneous. The pioneering study of ASM miners in Tanzania conducted by Bryceon and Jønsson (2010) showed that only 5 per cent of miners who had previously been involved in agriculture consider a return to agriculture. Most had a diverse set of interests in business enterprise and using ASM as a means of social mobility, which was not 'rash', even in the wake of a mineral 'rush'. The incentive mechanism, for ensuring that the land being mined was ecologically rehabilitated for future agrarian use, therefore appears even more limited. The miners may see their career path in the dialectical spiral that is negotiated through contrarian forces of short-term versus long-term gains. Ecological factors could be brought forth through appropriate regulatory mechanisms that respect the devolved nature of ASM at a social and economic development level, but modulate its environmental and health and safety impact.

Social ecology thus provides a hybrid approach to addressing the negative externalities of ASM, but without losing its core entrepreneurial 'highrisk high-reward' function in peasant societies. Mining cooperatives may be another important mechanism for implementing a more decentralised

6 Details on their ASM activities can be found on the website of UNIDO (n.d.). 
approach to ASM in the spirit of subsidiarity. Some of the past challenges of cooperatives, as documented by Levin and Turay (2008) could also be addressed by a social ecology approach. ASM, particularly in the gemstone industry, is a highly individualistic activity and has the potential to reduce itself to anarchistic arguments of autonomy from any regulatory mechanism. Fostering the value of cooperation through access to markets has often not been an adequate incentive for developing cooperative systems. Ecological and public health-oriented norms have greater potential for providing an incentive for cooperative development. Some form of standard-setting and regulatory enforcement can be better justified through such means. The dialectical principle of quantitative changes leading to qualitative changes can be embraced in the context of ASM by carefully monitored environmental health and safety education programs, coupled with enforcement against non-compliance. The proverbial 'carrot and stick' can find conceptual harmony through Bookchin's naturalism (Biehl 2015) and eventually lead to a dialectical 'turning point', whereby those engaging in ASM see ecological consciousness as a necessary part of their social system.

\section{Conclusion: The development imperative}

One cannot escape the fact that contemporary ASM is largely a phenomenon confined to the developing world, and is an adaptation strategy for poverty alleviation. It provides a conduit of livelihoods for vulnerable groups in society, but can also be a means of exploiting their vulnerabilities. The gender dynamics of ASM have been well studied in this regard and must also constitute an important part of the development goals that a social ecology paradigm may enable for this activity. During the 15-year period from the promulgation of the Millennium Development Goals until their date for completion in 2015, there have been several donor-driven programs to provide capacity around artisanal and smallscale mining. Many of these programs have arisen because of concern about mercury usage in ASM, which has been rising as a percentage of total mercury use, due to the obsolescence of other mercury uses in chloroalkali plants and electronics. A few programs have targeted the gemstone industry because of linkages to conflict or governance failures. The CASM network provided a clearinghouse for almost a decade for these various activities. We thus have 15 years of program evaluation that needs to be better evaluated and harnessed for future development planning, and could indeed be used to connect ASM activity to the new SDGs and the 2030 development agenda. 
No doubt the overall national development impact of large-scale mining in terms of fiscal flows and royalties to communities is likely to dominate the conversation in donor circles. Therefore, it is also essential that large-scale mining should have a more constructive relationship with ASM. Although there are cases where ASM activity has been allowed on large corporate mining concessions, a systematic approach with clear development indicators in mind has not been followed. The social ecology approach also has the potential to link these scales of activity to clear development metrics at different levels of governance. While large-scale mining can provide fiscal flows and development investment at a macro scale, ASM has the potential to deliver specific livelihood opportunities at a micro level.

Ecological consciousness can be the bridging element in this regard, and the social ecology approach to framing ASM allows us to consider this development imperative more directly. It is worth noting that political ecology (Peluso and Watts 2001) discourse in this regard has largely focused on a critique of resource scarcity determinism in conflict. Thus, political ecology has traditionally had a more diagnostic frame of analysis, whereas social ecology has been more prescriptive in its analytical trajectory. However, there can be a more constructive link between political ecology and social ecology in the context of ASM's contribution to development. The diagnostic insights of political ecology around land use and livelihood decisions of miners can be moved to the next phase through social ecology by developing a hybridised model of sustainable development and poverty alleviation. Social transformation through ecological learning and multi-tiered governance solutions will be essential to realise the development outcome of ASM. Perhaps Agrawal's (2005) notion of 'environmentality' can be used in this regard, building on Foucault's seminal work on knowledge and power in governance beyond conventional political institutions (governmentality). ${ }^{7}$ Such an approach has direct relevance to ecological and health impacts of highly devolved social activities such as ASM, whereby conventional governments recognise their limits of influence. The role of governments thus becomes one of enabling knowledge acquisition in communities. Governments can also provide a forum to negotiate the contradictions in development objectives, which the theory of dialectical naturalism suggests they will inevitably encounter.

7 Much of Foucault's work in this regard can be traced to his later years, particularly The Government of Self and Others: Lectures at the Collège de France 1982-1983 (Foucault 2010). 
This chapter has attempted to show that ASM cannot be romantically considered a manifestation of pristine poverty, and an ode to selfreliance and resourcefulness of the peasant. It is part of a broader human consumptive quest, and linked to the dominant capitalist industrial system, which we must find more pragmatic means of managing. No doubt it has the potential to provide economic resilience, but the ecological cost of the activity must be better internalised through a multi-level approach to its governance. Social ecology theory provides the most cogent way to grapple with this complex activity, which involves some level of inherent obsolescence, anarchist reward structures and considerable environmental cost. As we ponder the future of this challenging, entrepreneurial and adventurous arena of human endeavour, let us ensure that our decisions are driven by good research and deliberations with those desperate diggers who imperil their lives to bring us treasures from the bowels of the landscape.

\section{References}

Agrawal, A., 2005. Environmentality: Technologies of Government and the Making of Subjects. Durham NC: Duke University Press Books.

Bekker, I., 2015. 'On Pope Francis' Laudato si' and the ideas of Murray Bookchin.' Paper presented at the Transational Institute for Social Ecology, Patras, Greece.

Biehl, J., 2015. Ecology or Catastrophe: The Life of Murray Bookchin. New York and Oxford: Oxford University Press.

Binder, A. 1974. 'Programme in Social Ecology.' Environmental Education at Post Secondary Level. Vol. 1, Paris: OECD.

Bookchin, M., 1995a. Social Anarchism or Lifestyle Anarchism: An Unbridgeable Chasm. Edinburgh and San Francisco: AK Press.

Bookchin, M., 1995b. Philosophy of Social Ecology. 2nd edition. Montréal and New York: Black Rose Books.

Bookchin, M., 2005. The Ecology of Freedom: The Emergence and Dissolution of Hierarchy. Oakland, CA: AK Press.

Brincat, S. and D. Gerber, 2015. 'The Necessity of Dialectical Naturalism: Marcuse, Bookchin, and Dialectics in the Midst of Ecological Crises.' Antipode 47(4): 871-93. doi.org/10.1111/anti.12140 
Bryceson, D.F. and J.B. Jønsson, 2010. 'Gold Digging Careers in Rural EastAfrica: Small-ScaleMiners' Livelihood Choices.' WorldDevelopment 38(3): 379-92. doi.org/10.1016/j.worlddev.2009.09.003

Capra, F. and U. Mattei, 2015. The Ecology of Law: Toward a Legal System in Tune with Nature and Community. Oakland, CA: Berrett-Koehler Publishers.

Cartier, L.E., 2009. 'Livelihoods and Production Cycles in the Malagasy Artisanal Ruby-Sapphire Trade: A Critical Examination.' Resources Policy 34(1-2): 80-6. doi.org/10.1016/j.resourpol.2008.02.003

Foucault, M., 2010. The Government of Self and Others: Lectures at the College de France 1982-1983 (ed. Arnold I. Davidson, trans. Graham Burchell). New York: Palgrave Macmillan.

Hilson, G., 2010. “'Once a Miner, Always a Miner": Poverty and Livelihood Diversification in Akwatia, Ghana.' Journal of Rural Studies 26(3): 296-307. doi.org/10.1016/j.jrurstud.2010.01.002

Hilson, G. and A.J. Monhemius, 2006. 'Alternatives to Cyanide in the Gold Mining Industry: What Prospects for the Future.' Journal of Cleaner Production 14: 1158-67.

Kellogg Innovation Network, 2015. 'Kin Catalyst: Mining Company of the Future. Development Partner Framework.' Kinglobal.org. Available from www.kinglobal.org/mining-catalyst.html

Lahiri-Dutt, K., 2004. 'Informality in Mineral Resource Management in Asia: Raising Questions Relating to Community Economies and Sustainable Development.' Natural Resources Forum 28(2): 123-32. doi.org/10.1111/j.1477-8947.2004.00079.x

Levin, E. and A.B. Turay, 2008. 'Artisanal Diamond Cooperatives in Sierra Leone: Success or Failure?' Ottawa: Partnership Africa Canada. Available at www.africaportal.org/dspace/articles/artisanal-diamondcooperatives-sierra-leone-success-or-failure

Lindberg, M.C. and B. Purevjav, 2013. 'A Green Model for Mine Reclamation in Mongolia.' The Asia Foundation, 17 April. Available at asiafoundation.org/in-asia/2013/04/17/a-green-model-for-minereclamation-in-mongolia/ 
Mitroff, I. and J.R. Emschoff, 1979. 'On Strategic AssumptionMaking: A Dialectical Approach to Policy and Planning.' Academy of Management Review 4(1): 1-12.

Peluso, N.L. and M. Watts (eds), 2001. Violent Environments. Ithaca, NY: Cornell University Press.

Siegel, S and M.M. Veiga, 2009. 'Artisanal and Small-Scale Mining as an Extralegal Economy: De Soto and the Redefinition of "Formalization".' Resources Policy 34(1-2): 51-6. doi.org/10.1016/j. resourpol.2008.02.001

Sippl, K. and H. Selin, 2012. 'Global Policy for Local Livelihoods: Phasing Out Mercury in Artisanal and Small-Scale Gold Mining.' Environment: Science and Policy for Sustainable Development 54(3): 18-29. doi.org/10.1080/00139157.2012.673452

Smith, N., S.H. Ali, C. Bofinger and N. Collins, 2016. 'Human Health and Safety in Artisanal and Small-Scale Mining: An Integrated Approach to Risk Mitigation.' Journal of Cleaner Production 129: 43-52. doi. org/10.1016/j.jclepro.2016.04.124

Taylor, D., 1999. 'Begging for Change: A Social Ecological Study of Aggressive Panhandling and Social Control in Los Angeles.' University of California ( $\mathrm{PhD}$ thesis).

United Nations Development Programme (UNDP), 2015. 'Small-Scale Mining to Help Boost Social and Economic Development in the African, Caribbean and Pacific Group of States.' UNDP News Center, 15 July. Available at www.undp.org/content/brussels/en/home/ presscenter/pressreleases/2015/07/15/small-scale-mining-to-helpboost-social-and-economic-development-in-the-african-caribbeanand-pacific-group-of-states.html

United Nations Industrial Development Organization (UNIDO), n.d. 'What We Do: Mercury Programme.' Viewed at www.unido.org/en/what-we-do/environment/resource-efficient-andlow-carbon-industrial-production/watermanagement/mercury.html (site discontinued) 
Vatican Radio, 2015. 'Pope Francis Says Mining Sector Needs Radical Paradigm Shift.' 17 July. Available at en.radiovaticana.va/ news/2015/07/17/pope_francis_says_mining_sector_needs_radical_ paradigm_shift/1159107

World Bank, 2008. 'Communities, Artisanal and Small-Scale Mining (CASM): CASM's Holistic Approach to Small-Scale Mining Aims to Transform this Activity from a Source of Conflict and Poverty into a Catalyst for Economic Growth and Sustainable Development.' Issue Brief. Washington DC: World Bank. Available at siteresources. worldbank.org/INTOGMC/Resources/CASMFACTSHEET.pdf 
This text is taken from Between the Plough and the Pick: Informal, artisanal and small-scale mining in the contemporary world, edited by Kuntala Lahiri-Dutt, published 2018 by ANU Press, The Australian National University, Canberra, Australia.

doi.org/10.22459/BPP.03.2018.05 